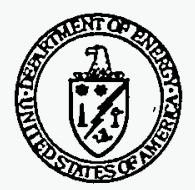

\title{
Management of Corrective Action Wastes Pursuant to Proposed Subpart S
}

\begin{abstract}
BACKGROUND: - Under Section 3004 (u) of the Resource Coñservation and Recovery Act (RCRA), owmersioperators of permitted or interim status, treatment, storage, and disposal facilitíes (TSDFS) are required to perform corrective action to address releases of hazardous waste or hazardous constifuents from solld waste management units (SWivus). Ôn July 27,1990 , the Environmental Protection Agency (EPA) proposed specific corrective action requirements under Part 264, Sübpart S of Title $\mathbf{4 0}$ of the Code of Federal Regulations (CFR). One poition of this pioposed rule, addressing requirements applicable to correctrve action management units (CAMUS) and temporary units (TÚs), was finalized on Fobruary 16, 1993 (58 FR 8658 et seq.). (CAMUs and TUs a tre RCRA waste management units that are specifically designated for the management of corrective action wastes.) Portions of the proposed Subpart $S$ rule that address processes for the

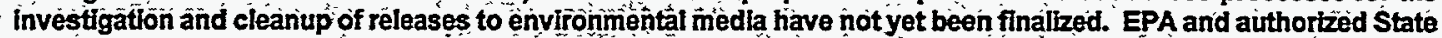
agencles, however, are currenttly using the investigation and cleanup procedures of the proposed rule as a framèwork for implementation of RCRA's corrective action requirements.

The performance of corrective action cleanup activities generates wastes that have to be characterzed and managed in accordance with appilcable RCRA requirements. This intormation Brief describes these requirements: It is one of a series of Information Briefs on RCRA Corrective Action:-
\end{abstract}

STATUTE: $\quad$ RERA as amended by the Hazardous and Solid Waste Amendments (HSWA)

REGULATIONS: , Proposed 40 CCFR 264, Subpart S (55 FR 30798 êt seq, July 27, 1990): 40 CFR 264, Subpart S (58, FR 8658 et seq; February 16,1993).

40 CFR $260,264,265,268,270$, and 271 :

REFERENCE: 1. "RCRA Regulatory Status of Contaminated Groundwater," EPAMemorandum to Region IV Director of Waste Management Division, November 13, 1986:

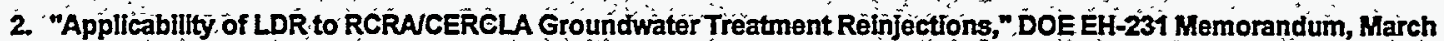
24, 1990.

3. "Corrective Aćtion Management Ünits and Temporary Units," U. S. Department of Energy, Office of Environmentai Guidance, RCRACÉRCLA Division, Infónormation Brief; EH-231-043/0394 (March 1994).

4. "Correctivë Action for Solid Waste Mànagement Units at Hazardous Waste Management Facilitî́es; Proposed Rule,", 55 FR 30798; Jufy 27, 1990 .

5. "RCRA Corrective Action Program Guide Interim Guidance, U.S. Department of Energy, Office of Environmental

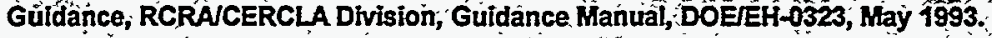

Are materials that are generated during a corrective action defined as solid wastes under RCRA?

Yes. The act of removing waste or contaminated media (including soil and debris) from SWMUs for subsequent treatment, storage, or disposal generates solid waste under RCRA.

\section{Aresolid wastes thataregenerated during a corrective action defined as hazardous wastes under RCRA?}

Some solid wastes that are generated during RCRA corrective actions may also be hazardous waste. The determination of RCRA status for corrective action-generated waste is very similar to that for newly generated wastes. Solid wastes are hazardous if they meet a listing description or are mixed with or derived from a listed hazardous waste [40 CFR 261.3(a)(2) and (c), respectively] or if they exhibit one, or more of the four hazardous waste characteristics. The listings include wastes from non-specific sources (40 CFR 261.31, F wastes), wastes from specific sources ( $40 \mathrm{CFR} 261.32, \mathrm{~K}$ wastes), and discarded commercial chemicals ( 40 CFR 261.33, $P$ and $U$ wastes). The characteristics of hazardous wastes are ignitability, corrosivity, reactivity and toxicity (40 CFR 261.21 - 24). While solid waste streams may be classified as hazardous by these listings or characteristics, wastes released into the environment need not meet these specific criteria in order to trigger RCRA corrective action. They only need to meet the broader statutory definition of hazardous waste contained in RCRA Section 1004(5) (see 55 FR 30809 et seq.). RCRA 1004(5) defines hazardous wastes as "solid wastes that cause or contribute to death or illness or pose a present or potential threat to human health or the environment." A solid wasteneed not be listed or exhibit one of the four hazardous characteristics to meet this definition.

\section{Which wastesare RCRAremediation wastes and how should they be managed?}

Remediation wastes are defined in the CAMU and TU final rule (58 FR 8658 et seq; February 16, 1993) and codified at 40 CFR 260.10. Under this definition, remediation wastes are those solid and hazardous wastes that are managed for the purpose of implementing corrective action. Remediation wastes include remediation-derived debris and media (including ground water, surface water, soils, and sediments) that contain listed wastes or exhibit a hazardous waste characteristic. According to 40 CFR 260.10 , for a given facility, remediation wastes may originate only from within the facility boundary; however, wastes originating onsite.but having migrated offsite may also be remediation wastes. Wastes generated as part of the site investigation (e.g., drilling muds) are also considered to be remediation wastes. Remediation wastes must be managed in accordance with the applicable waste management standards. New or "as-generated" wastes (either hazardous or non-hazardous) that are generated from ongoing operations notrelated to corrective action at a facility are ex́cluded from the definition of remediation waste.

The final rule also created two new types of waste management units, CAMUs and TUs, which are intended solely for the management 
of remediation wastes. Placement of remediation wastes into or within a CAMU does not constitute land disposal. of hazardous waste, and therefore does not trigger the land disposal restrictions [40 CFR 264.552(a)(1)]. In addition, CAMU's are not subject to the minimum technology requirements for land-based units [40 CFR 264.552(a)(2); see Reference 3].

\section{Does the designation of a CAMU affect the management of corrective action wastes?}

The Land Disposar Restrictions (LDRs) are among the most complex regulations potentially applicable to hazardous waste generated as a resilt of RCRA corrective action. The LDRs require that wastes meet treatment standards prior to land disposal. Treatment standards may be numerical standards based on best demonstrated available technology (BDAT) or specified methods of treatment. EPA recognized that the IDRs, which were designed to regulate newly generated waste and not eleanup wastes, may create cleanup disincentives. The proposed Subpart Srule provides someflexibility regarding compliance with the LDRs. This flexibility is embodied within the CAMU/TU final rule.

ACAMU is a new type of unit (defined under 40 CFR260.10) that is an .area within a facility that is designated by the Regional Administrator or the authorized State for the purpose of managing remediation wastes generated during corrective action. The CAMU is located where remediation wastes are managed; however, it does not have to be a contiguous area of existing contamination. The creation of a CAMU would allow cleanups to occur such that movement or consolidation of remediation waste within the CAMU and disposal of remediation wastes generated within the boundary of the facility would not trigger the LDRs. Furthermore, consolidation or placement of remediation wastes into or within a CAMU does not constitute creation of a unit subject to the minimum technology requirements (i.e., liner and leachate collection systems).

How do TUs affect the management of wastes generated during corrective action under SubpartS?

Many remedies will involve the short-term management (i.e., storage or treatment) of remediation waste. For example, wastes may be placed in tanks or containers prior to consolidation for treatment. Normally, RCRA regulations would require the owner or operator to comply withall requirements of 40 CFR 264 and obtain a full operating permit for storage and/or treatment of hazardous waste in such units (unless conducted in generator 90-day accumulation tanks or containers). The designation of the unit as a TU provides the flexibility for short-term management of remediation waste in tanks or container storage units without the burden of compliance with the full 40 CFR 264 standards and without permit requirements. A TU is a new class of unit created through the CAMU and TU rule to facilitate cleanups under RCRA corrective action. The rule would provide flexibility in complying with requirements such as design, operation, and closure requirements, so that only those standards required to protect human heaith and the environment during the operating life of the unit would be required. TUs have a maximum permissible life of no more than 2 years; after this time an owner or operator must submit a permit application and comply with the full 40 CFR 264 requirements (see 40 CFR 264.553).

\section{How does the "contained-in" policy affect waste management requirements?}

The "contained-in" policy establishes that contaminated media (e.g., soil or ground water) that contain a listed hazardous waste must be managed as a hazardous waste. Until the medium no longer "contains" a hazardous waste (to be determined at the discretion of the regulator), it must be managed according to the applicable hazardous waste management standards. This policy, applicable to Subpart S, is outlined in the EPA Memorandum "RCRA Regulatory Status of Contaminated Groundwater" (November 13, 1986) and in the DOE EH-231 Memorandum "Applicability of Land Disposal Restrictions (LDR) to RCRA/CERCLA Groundwater Treatment Reinjections," (March 24, 1990). 'Under this policy, soil or ground water deemed "clean" by the regulator may be returned to the ground without triggering RCRA Subtitle $\mathrm{C}$ requirements. However, full RCRA Subtitle $C$ requirements are applicable until the contamination is removed from the medium.

The publication ofEPA's debris rule (57 FR 37194 et seq; August 18,1992 ) codified the "contained-in" policy with respect to debris. According to the debris rule, debris (including debris generated as a result of the performance of corrective action) that no longer "contains" a listed hazardous waste is excluded from RCRA Subtitle C regulation as long as the debris does not exhibit a characteristic of hazardous waste. EPA or the authorized State determines on a caseby-case basis, the levels of hazardous constituents indicating that debris no longer contains a listed waste [40 CFR 261.3(f)(2)].

How would the presence of a mixed waste affect corrective action waste management requirements?

Under the Federal Facility Compliance Act (FFCAct) [P.I. 102386], mixed wastes are wastes that contain both hazardous waste (under Section 1004 of the Solid Waste Disposal Act) and source, special nuclear, or by-product material subject to the Atomic Energy Act (AEA) of 1954. These wastes are subject to the requirements of both acts, pursuant to DOE's May. 1, 1987, interpretive rulemaking under Section 161 of the AEA. From the regulatory perspective, therefore, the presence of a mixed waste at a RCRA corrective action site does not affect waste management requirements under RCRA; the same RCRA requirements apply whether or not the hazardous waste is a component of mixed waste (see 51 FR 24504 etseq; July 3, 1986). From a practical standpoint, the presence of mixed waste at a RCRA corrective action site does affect waste management requirements for a number of reasons, including (1) worker safety (e.g., protection from radiation exposure) during remediation efforts and (2) the need to identify appropriate remedial technologies. Furthermore, the FFCAct also requires DOE to develop mixed waste treatment capacity and technologies. Since mixed wastes are likely to be generated by DOE facilities undertaking corrective action, Site Treatment Plans, prepared in accordance'with the FFCAct's requirements, must consider the need to treat these wastes. (see 58 ER 17875 etseg.; April 6, 1993).

Questions of policy or questions requiring policy décîsions will not be deâlit with in EH 231 Informàtion Briefs unless that policy has already been established through appropriate documentation : Please refer any questions concerning the subject material covered in this Information Brief to Jerry Coalgate, RCRACERCL A Division, EH-231, (202) 586-6075.

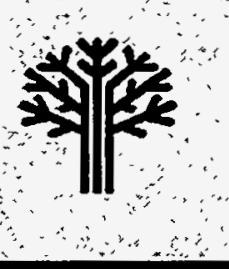




\section{DISCLAIMER}

This report was prepared as an account of work sponsored by an agency of the United States Government. Neither the United States Government nor any agency thereof, nor any of their employees, makes any warranty, express or implied, or assumes any legal liability or responsibility for the accuracy, completeness, or usefulness of any information, apparatus, product, or process disclosed, or represents that its use would not infringe privately owned rights. Reference herein to any specific commercial product, process, or service by trade name, trademark, manufacturer, or otherwise does not necessarily constitute or imply its endorsement, recommendation, or favoring by the United States Government or any agency thereof. The views and opinions of authors expressed herein do not necessarily state or reflect those of the United States Government or any agency thereof. 


\section{DISCLAIMER}

Portions of this document may be illegible in electronic image products. Images are produced from the best available original document. 